\title{
'How shall we kill him? By sword, fire or lions?': The Aramaic Targum and the Midrashic narrative on Haman's gallows
}

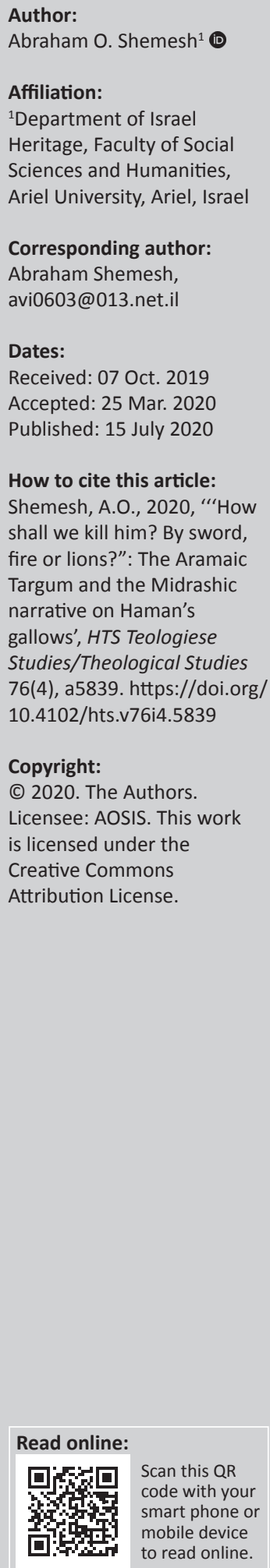

The Midrashic literature and biblical translations focus majorly on the verses that describe the gathering in Haman's house and the preparing of the gallows for Mordechai the Jew (Es 5:14). The goal of this study is to discuss the narrative shaped by the Targum and Midrashic sources and to examine both the realistic domain concerning methods of punishment that were suggested and the theological-educational meaning of the punishment and the type of tree chosen. Targum Rishon develops the contents of the conversation in Haman's house as to how Mordechai should be executed. While according to the text, the suggestion to hang Mordechai appears to have been the only method agreed upon by all those present at the meeting, Targum Rishon includes several forms of killing and torture that were proposed and considered. While Targum Rishon presents the theological meaning of the choice to kill Mordechai specifically by hanging him from a gallows, a Midrash aggadah attempts to clarify the species of the tree used to prepare Mordechai's gallows and comes to the surprising conclusion that it was a type of thorn tree. Regarding Haman's search for a suitable beam on which to hang Mordechai, Midrash Abba Gorion relates that the beam was found in the king's palace or, according to another opinion, the sawed beam found originated from Noah's ark.

Contribution: The Midrashic sources portray an entire scene that includes discourse, deliberations and choice in Haman's house and in heaven. It seems that the authors of the Midrash and the Targum not only clarify the text and complement the story by adding missing realistic details, they also enrich the text with new meanings that serve their theological concepts.

Keywords: Book of Esther; Midrash Abba Gorion; Targum Rishon; Esther Rabbah II; Haman; Mordechai; gallows; execution; crucifixion; ancient punishment methods.

\section{Introduction}

The Book of Esther is a short historical novella on the persecution and salvation from annihilation of the Jews who lived in the Persian kingdom during the reign of King Ahasuerus (on the various opinions concerning the historicity of the Book of Esther, see Middlemas 2011:145-163; Paton 1908:64-77; Weiland 2002:151-165).

According to the narrative, Haman the Agagite was appointed as the king's second-in-command and received much honour and esteem in Ahasuerus' palace (Es 3:1). Everybody bowed to him and paid him respect aside from Mordechai the Jew who refused to bow down. Because of this disparaging behaviour, Haman became enraged at Mordechai and decided to destroy him and his people throughout the empire (from a typological-comparative perspective, descriptions of similar conflicts between ministers in the courtyards of tyrannous kings and the persecution and salvation of congregations can be found in Jewish and world literature; see Klein 2002:218). On the structure of the plot and its motifs, see Loader (1978:417-421) and Berg (1979).

Haman was a household member at the king's palace. After he is invited to a banquet attended by the king, at Esther's initiative (Es 5:8), Haman gathers his loved ones at his house and tells them of his success, wealth and large family, and particularly of his high status among the ministers and the king's servants (Es 5:10-11). Haman proudly relates the events of his successful day and the invitation to another banquet to be attended by the king the next day (Es 5:12). The description of Haman's grief and desperation further on in the plot (Es 6:12-13), side by side with the description of his execution on the very gallows he himself had prepared for Mordechai (Es 7:9-10), contrast symmetrically with the current description of his wealth and success. Hence, the author describes Haman at the height of his power in order to subsequently stress the enormity of his downfall (Klein 2002:250). 
In the presence of his loved ones, Haman expresses his deep anger and frustration at Mordechai's position at the king's gate, reflecting his appointment as a minister and his proximity to the king (Es 5:13).

Haman's wife Zeresh and his loved ones advise him to destroy his rival by hanging him from a tall 'tree' (The Biblical Hebrew word etz (עr); literally, 'a tree' can refer to a live tree or a wood - pole, gallows or other wooden object). They suggest that he should prepare the gallows, and in the morning ask the king, whose support he has, to hang Mordechai. Haman takes their advice and prepares a 50-cubit high gallows (Es 5:14). That night, the king cannot sleep and orders his servants to read for him the court records (Es 6:1). They tell him that Mordecai interceded in intrigue against his life and that Mordecai never received any esteem for that (Es 6:2-3).

However, when Haman comes to the palace to ask the king to hang Mordechai, his request is not heard and, furthermore, he also meets with much contempt (Es 6:4-10). The king orders him to lead Mordechai through the town streets, riding the king's horse and wearing fancy royal clothing (Es 6:11). As stated, further on in the narrative, Haman experiences a severe downfall and is hung from the gallows that he himself prepared for Mordechai (Es 7:10).

The story related in the Book of Esther portrays the tension between the persecuted people of Israel and the hostile gentile environment. This hostility is manifested in various spheres, both wide (the masses) and narrow (specific characters). The struggle between Haman and Mordechai is not a mere personal 'conflict between ministers' but rather a struggle between two figures that represent wider groups. In the book, Haman personifies evil and embodies the archetype of all enemies of the exiled Jewish people.

Mordechai, persecuted by Haman, embodies the righteous and the good-seeking person (Es 10:3) and represents the entire people of Israel, persecuted by their enemies. Hence, the plan to hang Mordechai and preparing the gallows for this purpose reflect the desire to harm the entire people of Israel (Klein 2002:217).

\section{Haman's gallows in the Aramaic Targum and in aggadic homilies}

The biblical translations and the Midrashic literature focussed majorly on the verses that describe the gathering at Haman's house and the preparing of the gallows. The Midrashic sages discussed the meeting at Haman's house, all the while expanding and developing the contents of the conversation and the consultation as to how Mordechai should be executed. While according to the text, the suggestion to hang Mordechai appears to have been the only method agreed upon by all those present at the meeting, the Aramaic translation includes several forms of killing and torture that were proposed and considered, although these were subsequently rejected in favour of the suggestion of hanging from a tree. While the Aramaic translation presents the theological meaning of the choice to kill Mordechai specifically by hanging him from a gallows, a Midrash aggadah attempts to clarify the species of the tree used to prepare Mordechai's gallows and comes to the surprising conclusion that this was a type of thorn tree. Another Midrash relates that Haman had difficulty finding a beam to hang Mordechai, until finally discovering in his house a beam originating from Noah's ark.

\section{The purpose of the study and the research questions}

The purpose of the current study is to discuss the narrative shaped by the Targum and Midrashic sources. I shall examine both the realistic domain concerning methods of punishment that were suggested and the theological-educational meaning of the punishment and the type of tree chosen. The research questions are:

1. What role do the proposed killing methods have within the realistic circumstances of the ancient world, and what concept underlies their proposal and rejection?

2. What possible message underlies the suggestion that Haman's gallows originated from the garden of the king's palace or Noah's ark?

3. What theological-educational concept underlies the suggestion that Haman was hung on a thorn tree?

\section{The methods proposed at Haman's house for taking action against Mordechai: The interpretation by the Aramaic Targum}

Two Judeo-Aramaic translations of the Book of Esther are known to us. One, called the Targum Rishon (first translation), provides a verbal translation with a small number of Midrashic expansions, while the other, called the Targum Sheni (second translation), is a homiletic translation that encompasses a large amount of Aggadic material. According to their content, style and literary character, these two translations appear to have been redacted no earlier than the 6th century AD, and some date them even later, in the late 8th century. Nevertheless, ancient interpretive and Midrashic material is ingrained in these translations (on these translations, see Grossfeld 1983, 1994).

The Targum Rishon on Esther 5 vividly describes the deliberations concerning how best to harm Mordechai, by those present at Haman and Zeresh's house:

His wife Zeresh and all his loved ones said to him: With your permission we will say one thing. What shall we do to Mordechai the Jew? If he is one of the righteous people that were created in the world, then if we shall kill him by sword the sword will reverse itself and attack us. Should we hand him over to be stoned? David already stoned Goliath the Philistine. Should we put him in a coppery vessel? It was already rent asunder and Manasseh was released from it. Should we cast him in the sea? The sea was already parted and the Israelites came out of it and passed through. Should we cast him into a raging fire? Hanania, Mishael, and Azaria already came out of it. Should we throw him into a lions' den? The lions did not hurt Daniel. Should we throw him before dogs? The mouths of the dogs were already closed in 
Egypt when the Israelites left. Shall we banish him to a desert? In the desert the Israelites already expanded and grew. What other type of death could we bring upon him? Should we throw him in prison? Joseph was already raised to the throne from prison. Should we slash his throat with a knife? The knife already reversed itself for Isaac [=in the Binding of Isaac]. Should we blind him and leave him? He will kill us as Samson did. The calamities this man might cause cannot be foreseen. What should we do? We should prepare for him a large cross-shaped gallows and his blood will be spilled on the door to his house. His body will be displayed on the cross and all the Jews and his friends and loved ones will see it [...] and Haman son of Hamdata did not sleep until he had gone and brought carpenters and hewers [of wood for preparing the fire to make the knife]. Carpenters who prepare the gallows and hewers who prepare the metal knife. And the sons of Haman rejoiced and his wife Zeresh played the violin with the evil Haman (my translation from the Aramaic). (v. 14)

Mordechai was perceived by the participants as a dangerous person who if not destroyed might cause a great deal of trouble. The Targum begins by portraying each proposed manner of killing, followed by the reason it was rejected. The recurring principle is that each proposed method of killing was rejected because of the concern that it might fail.

The exegetist portrayed a series of failed attempts to punish individual figures or collectives, as described in biblical stories or in rabbinical interpretations of biblical stories. Haman and his supporters are allegedly aware of the spiritual power of the Jewish righteous people and the protection they are granted ('If he is one of the righteous people that were created in the world'), and hence they assume that if Mordechai is righteous, he might be granted a miracle of salvation.

Clearly, the foundation for this reasoning is located in the sages' world of beliefs rather than in that of Haman himself (on the power and the virtue of the righteous in sages' literature, see Babylonian Talmud 1882, Chagigah 12b; Babylonian Talmud 1882, Sanhedrin 93a). The phenomenon of gentile 'recognition of' or 'faith in' Jewish outlooks, sometimes while utilising them negatively against the Jews themselves, is represented in various places in Jewish literature. One example of a gentile who holds a Jewish outlook and uses it negatively against the Jews is evident in the story of the Midianite daughters and their moral corruption. Balaam advises Balak to corrupt the daughters of his own people in order to harm the people of Israel, as 'the God of this nation hates harlotry'. Namely, he believes that this is true and therefore can be used for practical purposes (see Jerusalem Talmud 1523, Sanhedrin 10:2, 28d; Babylonian Talmud 1882, Sanhedrin 106a).

This element, intentionally controlled by the redactor of the Talmudic sugya or the exegetist, is aimed at fulfilling ideological-literary needs and conveying messages in which the exegetist has a stake. In our context, it may be assumed that the emphasis on the righteous person's power has an educational purpose. It intends to convey the message that the Jews' enemies are aware of the power and immunity accorded to those who follow God's way. In times when the Jews were subjected to distress and oppression by the general society, such insights were capable of granting them strength as well as the hope that the righteous among them had the power to protect the entire community.

\section{The suggestions for harming Mordechai: From the realistic to the theological}

The Midrash discusses many varied methods of execution or severe physical harm, even without killing. It is not clear why the exegetist chose to portray the methods of killing in the current order, as some consistency regarding the chronological order of the miracles could have been expected. For instance, the parting of the Red Sea is brought before Joseph's story and the blinding of Samson after the miracle that befell Daniel and his friends. No hierarchy of increasing severity (from easy to grave) can be identified in the order of the punishments.

The punishment methods proposed in the Targum are taken from biblical stories. All of them are mentioned explicitly or are interpretations of the biblical text (see below). The exegetist sought stories of miracles mentioned in the scriptures and therefore chose these and not others. It is not clear to what degree the forms of punishment brought in the Targum Rishon were common in the era of its redaction (6th-8th centuries). If this was a tradition from the Mishna and Talmud eras, it may have been influenced by the common reality in the Roman-Byzantine world. As we shall see below, some of the types of punishment were customary during the time of the Aramaic Targum. In such cases, it is to be assumed that this had relevant educational meaning, as discussing a familiar phenomenon might have left an impression and aroused identification among the audience. Moreover, many of the punishment methods that shall be mentioned include (or are similar to) the four methods of execution legislated in rabbinic literature, namely, stoning, burning (internal, with molten lead), beheading and strangulation (Albeck 1952; Mishnah Sanhedrin 7:1-3). These methods without a doubt were familiar to the Jewish audience.

In the following lines, I shall discuss each of the punishment methods proposed:

1. Killing by sword: According to biblical literature, killing by sword (stabbing or beheading) was customary in times of war (Nm 31:8; Is 13:15), but it is also an execution method (Jdg 8:20. On this method in Sages' literature, see Albeck 1952; Mishnah, Sanhedrin 7:3; Babylonian Talmud 1882, Yevamot 77a and at length Theis 2016:254). In the narrative of the Targum, Haman and his advisors rejected this method, arguing that they had already been hurt by it in the past. In contrast to the other justifications that link the rejection of the killing method to a well-known event, in this case, Haman and the members of his household note that they were harmed by the sword of the Jews but they do not state which event this denotes. It probably alludes to the execution of Agag, Haman's forefather (compare Es 3:1), whose body Samuel beheaded (slashed, cut) with a sword (1 Sm 15:33. The sword is not mentioned explicitly, and the word used, רסש, is a hapax. However, it seems that it means 'to kill by sword', or even 'to behead'). Notably, 
this event was stressed in the Midrashic literature. According to one tradition, after Samuel slashed Agag's body, he cut up his flesh and fed it to ostriches (Mandelbaum1962:45; Yalkut Shimoni 1975, II:724).

2. Stoning: Stoning is an ancient punishment technique and, in some places, it is still customary in modern times, such as in Afghanistan (Mullen \& Popalzai 2015). In the scriptures, it is mentioned in the context of public punishment of sinners by the masses ( $\mathrm{Lv} 24: 23$; Nm 15:36; Jos 7:25). Theis argues that we have no testimonies of such punishment in ancient Egypt and Mesopotamia, and he rejects the arguments of those who claim that it was practised there (Theis 2016:255-256). According to the Targum, Haman preferred not to stone Mordechai because of the precedent of David who overcame Goliath by pelting him with smooth stones (1 Sm 17:49). The exegetist assumes that punishing with stones might be in Mordechai's favour, but it is not clear how. In contrast to the other cases where the Jewish people managed to evade the punishment given to them, in the case of David and Goliath the stones were thrown in order to vanquish the enemy. Hence, as perceived by the exegetist, any event, victory or evasion by Jews that includes an element resembling the punishment method discussed would justify Haman's avoidance of its use.

3. Killing with a coppery vessel: According to the Midrashic interpretation, the King of Babylon cast Manasseh, King of Judah who reigned in the 7th century BC, into a coppery vessel (dud nehoshet) and lit a fire underneath. This method of punishment is not mentioned explicitly in the scriptures. Perhaps, it is based on 2 Chronicles 33:11

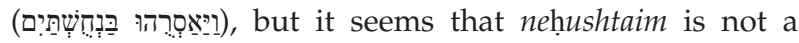
vessel but a device designed for binding both legs of the prisoner (see 2 Sm 3:34 and at length Zakovitch \& Shinan 2017:126).

In this event, Manasseh repented and called upon God for help, and he was miraculously saved. The vessel split open and he managed to escape (Jerusalem Talmud 1523, Sanhedrin 10:2, 28c). The source does not specify whether the vessel contained any liquid. Death by boiling was known in the past in various parts of the world (Abbott 2012:41-45). There is no information on killing in a vessel, with or without water, in the time of the Mishna and the Talmud. It is not impossible that the sages took this method of killing from the reality known to them. According to the Targum, Haman is concerned that a similar miracle will befall Mordechai, and he will manage to extract himself from the boiling vessel, and therefore he does not prefer this method of killing.

4. Throwing in the sea: Execution by casting people in the sea appears to have been carried out by tying them up or throwing them into deep waters far from the beach. Throwing people into a water source as a method of execution was customary in the Roman and the Byzantine world (Poena cullei). Punishing a person who murdered his parents or a relative (parricide) involved placing him in a leather sack together with several animals and throwing the sack into the water (on the Roman law see Bauman 2005:23; Robinson 2007:44-47).
Casting into a water source was mentioned in the scriptures in the context of the Pharaoh's decree to throw the male Israelite babies into the Nile (Ex 1:24). Notably, in the story of Jonah (1:12), the sailors threw him into the stormy sea at his own request, with no intention of executing him (but they certainly expected that they were killing him by doing so) rather in order to save those in the ship. The exegetist links the possibility that Mordechai will be saved from a water source to the splitting of the Red Sea, where the waters separated and the Israelites, fleeing the Pharaoh and his forces, crossed the sea unconcernedly on dry land (Ex 14:21).

5. Casting into a fire source: Throwing a person into fire is mentioned in the biblical stories and in several Midrashic sources. Execution by burning is a common punishment in biblical laws, and it was customary as a punishment in ancient Egypt as well (Gn 38:24; Lv 20:14; 21, 9; Jos 7:15, 25. On burning humans in Ancient Egypt, see Holm 2008; Theis 2016:250). This punishment was given, among other things, for the sin of adultery or forbidden marriage ties, and it appears in the story of Tamar and Judah, and as the punishment meted out to the corrupting daughter of a priest (see Gn 38:25; Lv 21:9; Theis 2016:249-251).

Throwing one into a furnace was a Babylonian punishment technique. In the Book of Daniel (3:21), it is related that Daniel's three friends did not obey the king's order to bow to the goldenidolerected by Nebuchadnezzar. They remained loyal to their religion and faith, and, as a result, they were punished and thrown into a fiery furnace. This element also appears in the Midrash that tells of a similar punishment meted out to Abraham (Theodor \& Albeck 1903:361-364). Nimrod threw Abraham into the fiery furnace because of his monotheistic faith and his disrespect for his father's idols.

The exegetist chose to mention the story of the salvation of Daniel's friends and not the story of Abraham's salvation, apparently because he preferred the explicit biblical source and perhaps because of its relative proximity to Mordechai's time, which might have increased the concern of a recurring miracle (on the historical background of Book of Daniel, see Koch 2001:421-446; Segal 1967:729-756).

6. Casting into a lions' den: Throwing one into a pit with ravenous lions appears in the story of Daniel, who similar to his three friends does not obey the king's decree to refrain from entreating either people or God for 1 month, aside from Darius (the Mede). Haman's concern that the lions would not hurt Mordechai or that nothing would happen to him if he were to be thrown into a furnace (see above) has to do with the fact that in both stories, of Daniel and of his friends, they are granted full salvation. Leaving the fiery furnace or the lions' den, those around them saw that they were not harmed at all, and that their bodies and clothes remained completely unscathed (Dn 3:27; 6:24).

Moreover, in both stories, the king's ministers, who wished to harm Daniel and his friends, ultimately received the very same punishment they sought for the 
hated Jews. In the case of Daniel's friends, they caught fire from sparks emitted by the burning furnace and were killed (3:22); in the case of Daniel, the king ordered the informant ministers thrown into the lions' den, where they were devoured (6:25). Hence, both stories indicate the possibility that Mordechai will not be hurt, if he is as righteous as Daniel and his friends who were saved from a similar situation.

7. Throwing before dogs: Killing people using aggressive dogs was not mentioned explicitly in the scriptures. According to 1 Kings 21:19-24 and 2 Kings 9:35-36, dogs licked the blood of Ahab and ate the body of Jezebel after their deaths (on the situation of a dangerous assault by a group of dogs, see Ps 22:17). The Talmudic literature mentions urging a dog to attack a man in the context of tort law but apparently not for the purposes of killing (Babylonian Talmud 1882, Baba Kama 24b).

The Targum Rishon speaks of throwing Mordechai to lions and dogs. Notably, the execution of an accused using predators of all types was customary in the Roman world as well (Damnatio ad bestias). Criminals and those sentenced to death were thrown into the arena in amphitheatres as punishment (Futrell 2001:28-29). The author of the Targum may have chosen to present a method with which he was familiar and which suited the idea he wished to present. The suggestions to harm Mordechai in this way were rejected because when leaving Egypt, the dogs avoided hurting the Israelites (Ex 11:7), and the exegetist assumed that this could be a concern in the case of Mordechai as well.

8. Banishing to the desert: In ancient Jewish sources, the term 'desert' (midbar) represents an uninhabited and untilled area. This geographical region might be deserted and hot, and sometimes even covered with tangled growth inhabited by dangerous animals (Ha-Reuveni 1991:23-30). Intentional banishing of people to the desert, far from habitation, was intended to cause their death by heat, hunger and thirst, or by predators. Banishing a person to the desert with the intention of causing his death is not explicitly mentioned in the scriptures. In the story of the sale of Joseph, Reuben suggests that the brothers throw him "into this cistern here in the wilderness' (Gn 37:22). Indeed, this is not a case of banishment, but stressing that the cistern is located 'in the wilderness' demonstrates the helplessness of an isolated person in a region with no human activity and no possibility of receiving help.

The bitter fate of people who lost their way in the desert, far from human habitation and in the harsh conditions of heat, lack of water and shade, is evident from the story of Abraham who banished Hagar and of Elijah who fled Jezebel (Gn 21:14; 1 Ki 19:3-8). According to the 'reverse Exodus' motif in Ezekiel 20:21, God says he will bring the people out of Babylonia to the wilderness, and then kill most of them there.

Haman and his household reject the idea of banishing Mordechai to the desert, claiming that the Israelites survived in the desert for 40 years because they were the recipients of various miracles (manna, quail and water). Hence, there is a concern that Mordechai too will be granted a similar miracle if he were to be banished to the desert.
9. Prison: Imprisoning of people was described in various sources in the scriptures and rabbinical literature (Jr 37:4; Babylonian Talmud 1882, Gittin 58a). In the ancient world, the prison was a harsh facility and life in prison was a source of suffering. Tough conditions in prison, such as deficient food, damp pits, and lack of air and light, could endanger the prisoner's health and even cause his death (Welch 2004:26-27).

Imprisoning Mordechai would undoubtedly have been a severe punishment and, as perceived by Haman and his supporters, might have neutralised his deleterious activity. However, Haman rejected the possibility of Mordechai's imprisonment, citing the historical precedent of a miracle that occurred in this context, that is, the fact that Joseph not only survived his time in prison but even proceeded from there to a royal position (Gn 41:14-46). Namely, such a miracle might occur if Mordechai were to be imprisoned.

10. Slaughtering: Killing by slitting one's throat with a knife as a form of execution was mentioned in the scriptures in the story of Nebuchadnezzar, the king of Babylon, who slaughtered Zedekiah's sons before his very eyes (2 Ki 25:7; and compare $\mathrm{Nm}$ 14:16). Haman rejects the possibility of killing Mordechai in this way, claiming that Isaac too was sentenced to be slaughtered by his father, but the decree was cancelled and he was saved. Hence, it is possible that a similar miracle would occur for Mordechai as well.

11. Blinding: Blinding an accused was one of the cruel methods of punishment customary in the ancient world (on blinding in the Greco-Roman World, see Pearman 2010:89; Rose 2003:81-82). This punishment was usually used as revenge or to torture the accused rather than to cause a person's death (Goes 2013:234). The scriptures contain several stories of people who were blinded as punishment - Samson and King Zedekiah. It is related to Zedekiah that Nebuchadnezzar, the king of Babylon, slaughtered Zedekiah's sons before his very eyes and then blinded him and led him to Babylon in chains (2 Ki 25:7).

Inspired by the story of Samson, whose eyes were gouged out by the Philistines (Jdg 16:21), but who employed the last vestiges of his strength to take revenge against them and kill many Philistines (Jdg 16:29-30), Haman avoided utilising this form of punishment. At the time the Targum was written, blinding the accused was a customary punishment in Byzantium (Lascaratos \& Marketos 1992:133-144; Stump 2017:46-54).

12. Hanging from a 'tree' (crucifixion): After all the methods proposed were rejected, the group decided to kill Mordechai by hanging him from a tree (Es 5:14). The translation notes that this means 'crucifixion', that is, tying or nailing the arms and legs of the person executed to a cross-shaped tree (Cook 2014; Robison 2002:25-59). In fact, other Aramaic translations, that is, Onkelos, the translation attributed to Yonatan ben Uziel, and the Yerushalmi translation, also translate the phrase 'hanging from a tree' as crucifixion (see their translation on Dt 21:22-23). This method of execution was common in ancient cultures, such as among the Persians, Seleucids and Carthaginians (Samuelsson 2011:2-35)', and also in 
the period of the sages, both in the Greek and Roman world in general and in the Land of Israel in particular (Bammel 1970:162-165; Zias 1985:22-27).

Some think that hanging one from a tree, as mentioned in the Book of Esther (2:23), refers to impaling the accused on a pointed stick (Haupt 1908:97-186; Theis 2016:251). Execution in this manner was mentioned in various Mesopotamian sources (for instance, in the Laws of Hammurabi No. 153 with regard to a woman who caused her husband's death) and in ancient Egypt (on impalement in Babylonia, see Herodotus 1926, III:159; Jacobs 2009:121-153; Theis 2016:251-253). The Targum explains that the crucifixion method was chosen because of the absence of any historical case wherein a miracle saved a Jewish person who was to be executed by hanging, which might presage Mordechai's salvation.

The Midrash emphasises another aspect of the choice to hang Mordechai from a 'tall tree', that is, the opportunity to publicise his execution. In contrast to other methods of killing, such as casting one in a distant desert or in the sea, with no audience present, crucifying him on a tall tree in a populated area would be visible to everyone. The Targum stresses that those gathered in Haman's house agreed that Mordechai should be hung near his house, in a Jewish environment, and would thus be seen by all the Jews, as well as his friends and loved ones.

\section{Why did Haman think that God would not intervene and no miracle would occur if Mordechai were to hang?}

The premise of those gathered in Haman's house was that if a certain method of killing did not succeed in the past when utilised against some Jewish person or group, it should be avoided. Hence, as there is no historical precedence for salvation in the context of hanging from a tree, this method was preferred. The question is whether and why would God not be inclined to save Mordechai in the case of an attempt at crucifixion? Why is it likely that a miracle would occur once again if it had already occurred in the past in a certain manner of killing?

This assumption may be based on the outlook that God might act to repeal certain methods of harm in particular, and especially those related to natural elements that he himself created (lions, dogs, the sea, natural forces such as water and fire, and survival in harsh conditions - the desert). Hence, he is capable of neutralising them when they operate against his interests or of utilising them for his loved ones. Haman and his household think that when salvation was effected in a certain way in the past, this proves God's control of a certain element and raises the possibility that he might utilise this same punishment in the future against enemies of the Jews.

Such a view appears in other Midrashic sources as well. One example is evident in the Talmudic story of Titus who burnt down the Second Temple in $70 \mathrm{AD}$ at the end of the Great Revolt (on the Great Jewish Revolt, see Kasher 1983; Rappaport 1984:274-302). According to the Jewish Aggadic story brought in the Babylonian Talmud 1882 (Gittin 56b), after Titus destroyed the city, he entered the Holy of Holies and desecrated the sacred site. He stabbed the parochet (curtain covering the ark) with a sword and blood came forth, persuading him to think that he had killed the God of the Jews. When returning to his country by sea, he encountered a strong storm that threatened to overturn his ship.

Titus claimed that the power of the Jewish God is in the water. God split the sea for the Israelites during the Exodus (Ex 15:19) and also drowned Sisera and his chariots in the Kishon River (Jdg 5:21). Titus declared: 'If he is mighty - may he come up on to the land and fight me!'. Namely, the God of the Jews controls certain elements (water, sea, etc.) that enable him to punish or to save.

Titus challenges God to fight him on land, assuming that the power of God is limited there. The God of the Jews disproves the mistaken view of Titus and demonstrates his control on land as well through a gnat that enters Titus' brain and pecks at it for 7 years.

Hence, the deliberations of those gathered are in fact a manifestation of Mordechai's power. All the killing techniques proposed, aside from the last (crucifixion), are irrelevant, as God controls them, and therefore it is necessary to seek a 'safe' technique that will not be unexpectedly foiled.

\section{Where did Haman obtain the beam for hanging Mordechai? - The version cited by Midrash in Midrash Abba Gorion and Yalkut Shimoni}

The Midrash in Midrash Abba Gorion, a late collection of Midrashim (c. 10th century) which was familiar to medieval sages, and Esther Rabbah II, the later part of the Esther Rabbah Midrash (c. 10th-11th centuries), relate that Haman searched for a suitably sized beam for executing Mordechai (Buber 1887):

Haman took a cedar (in the text: erez) from ginat ha-bitan [the garden of Ahasuerus' palace], its length fifty cubits and its width twelve cubits. Some would say Parshandata his son was a governor in Cardonia and he took it from Noah's ark. (p. 37)

According to the first opinion of the Midrash, the beam was found in the palace. It seems that the exegetist wanted to express the idea that it was very easy to find it, or the lack of caring of the king to the fate of Mordechai. According to a second opinion, the sawed beam found suitable for the hanging task was found in Noah's ark, which was large and built of long beams. This beam was brought from a distance, from Cardonia, a place in the vicinity of the Ararat Mountains, where his son had served in a position of authority (Kardunia or Cordyene is a district lying to the east of the river Tigris, south of Armenia. See Jastrow 1903, II:1412). 
Other Midrashic sources note that beams from Noah's ark were collected by various people from biblical times, and they put them to use. The Talmudic tradition in Sanhedrin $96 \mathrm{~b}$ relates that Sennaharib found a beam from Noah's ark and worshipped it. The two events have in common the use of Noah's ark for negative purposes - killing and idolatry. The exegetist might have wanted to show the distorted use made of the ark's remains. The ark served as a source of life and renewal of the world in the face of evil, while two people known to be evil, Parshandata and Sennaharib, used it for negative purposes.

According to the version of Yalkut Shimoni, Haman had difficulty finding a beam and, surprisingly, ultimately found it in his own house (Yalkut Shimoni 1975, I):

Have a pole set up, reaching to a height of fifty cubits - [...] Haman sought a fifty cubit beam but could not find one, aside from a beam that was in his own house, as his son Parshandata was a governor in Cardonia and he took one sawed beam from Noah's ark. (p. 155)

The beam was brought from afar and the bother of transporting it seems to have been worthwhile. Haman appears to be lucky because it solved his problem. Nevertheless, further on the circumstances change. This very beam becomes his wrongdoing and he himself hangs from it.

\section{Was Haman's gallows prepared from a thorn tree? (Es 5:14) - Midrash Abba Gorion and Esther Rabbah II commentary}

The author of the Book of Esther relates that Haman prepared a tall tree from which to hang Mordechai (5:14).

From a narrative standpoint, the question of exactly what tree was used to prepare the gallows is completely marginal. However, Midrash Abba Gorion, a late collection of Midrashim (c. 10th century) which was familiar to medieval sages, and Esther Rabbah II, the later part of the Midrash (c. 10-11th centuries), express interest in this issue (on Midrash Abba Gorion and Esther Rabbah II see Atzmon 2005, II:16, 2011; Buber 1887:I-IV, VIII; Elboyim 2011; Rabinovitch 1976:161-170).

The Book of Esther laconically describes the preparation of the tree for hanging Mordechai. The author of the Midrash, in contrast, relates that choosing a suitable tree was a major issue, arranged by God himself (Buber 1887:41-42; Esther Rabbah:27 1885-1887). The exegetist believes that this was not a simple gallows but rather the species of tree from which it was produced might indicate the cause of Haman's downfall. The Midrash describes the process of choosing the tree as follows (Buber 1887):

So they hanged Haman on the gallows. What tree was it made of? The sages said, When [Haman] came to prepare it, the Holy One Blessed be He called upon the trees and said to them, who will sacrifice itself to hang this evil man. The fig said: I will sacrifice myself, as from me are the first fruit brought, and moreover, the Israelites were likened to me [...] The grapevine said: I will sacrifice myself because the Israelites were likened to me $[\ldots]$ The pomegranate said: I will sacrifice myself because the Israelites were likened to me [...], The nut said: I will sacrifice myself because the Israelites were likened to me [...], The citron said: I will sacrifice myself because the Israelites were likened to me $[\ldots]$, The myrtle said: I will sacrifice myself because the Israelites were likened to me [...], The olive said: I will sacrifice myself because the Israelites were likened to me [...], The apple said: I will sacrifice myself because the Israelites were likened to me $[\ldots]$, The palm said: I will sacrifice myself because the Israelites were likened to me [...], The willow said: I will sacrifice myself because the Israelites were likened to me [...], The cedar said: I will sacrifice myself because the Israelites were likened to me [...]. Then the thorn came before the Holy One Blessed be $\mathrm{He}$ and said to him: Sovereign of the world, you are subject to neither bias nor bribery. I, who have no special virtues to cite, I will sacrifice myself to hang this impure man. Immediately, it was accepted by Him. At that time the evil man ordered his servants to prepare a tree fifty cubits tall, as he said so that it would be seen by the entire country. (pp. 41-42)

Haman orders that the tree for hanging Mordechai be prepared only once. God has chosen the appropriate tree for hanging Haman himself. According to the narrative, the decision and the selection of the tree are under the full control of Haman and his household (5:14). However, the exegetist stresses that in fact it is God who decides and determines man's fate rather than man himself.

Haman chose a particularly high tree in order to publicise the elimination of Mordechai, his enemy. The Midrash surprisingly ignores this meaningful detail and does not present the trees as voicing any claim associated with the required height. When considering height, the most appropriate tree for the task would appear to be the Lebanon cedar that reaches a height of over $40 \mathrm{~m}$, but it is nevertheless rejected.

Several of the other plants that take part in the discussion, such as the myrtle, the pomegranate and the vine, and certainly the thorn tree that is eventually chosen, do not fit the height criterion ( 50 cubits, about $25 \mathrm{~m}$ ) nor the necessary strength demanded of a tree intended for hanging. Hence, it is clear that the exegetist completely abandoned the realistic sphere and chose to present the trees based on their symbolism in the biblical verses. The message of the exegetist is that in a miraculous reality, matter loses significance and it is the metaphysical that affects the fate of the individual or of the collective.

Analysis of the arguments and justifications brought by the plants in support of their suitability as a tree for hanging Haman indicates two main features:

1. The tree as symbolising the Israelites as a nation: The literary use of plants as symbols, images or metaphors is a conspicuous element in the Midrash. Plants symbolise the 
nation's forefathers, people in a heterogeneous society, for instance, the virtuous and the evil, and even the entire Jewish collective (Ps 1:3, 92:13; Mandelbaum 1962:414-416; Leviticus Rabbah 1885-1887:44b). The large majority of the trees are characterised by the author of the Midrash as plants 'used to typify Israel', most conspicuously the five fruits of the seven species for which the Land of Israel was praised. The uniqueness and special traits of the Jewish collective are embodied by the trees and their unique qualities and constitute the basis for the ability to withstand and survive Haman's annihilation decrees, as the author of the Midrash believes that the battle against Haman's hatred occurs at the metaphysical level.

2. The Israelites' adherence to the Torah and to the religious precepts: Among the trees mentioned, the citron (Citrus medica) is the only one not presented by the exegetist as directly symbolic of the people of Israel. The citron declares that its fruit is used for a blessing on the Festival of Tabernacles, that is, it reflects the Israelites' observance of the religious precepts, which may protect them from harm.

\section{Seeking a tree for hanging Haman and the choice of the prickly thorn: Educational messages}

The description of the process of seeking the right tree adds an additional level to the events that occur on earth - a hidden positive occurrence, in spite of the harsh reality, and divine intervention. It may be necessary to connect the Aggadah to the historical-economic-political circumstances of its author. The exegetist refers to the story of the Book of Esther while awarding renewed meaning to the occurrences in order to instil hope, consolation and encouragement in his readers who are experiencing a bitter reality or a historical event involving suffering and distress (various scholars have related to the role of the synagogue and the homily as a way of strengthening Jewish communities or towns. See Mack 1989:27-33; Shinan 1987:18-19). Another educational aspect is stressing the role of community members' sacrifice and modesty in the process of rescue and redemption. The choice of the thorn as the cause of Haman's final downfall is encouraging for people who are considered bereft of all virtues but are endowed with modesty.

In spite of the detailed arguments of each of the trees, God chooses the thorn tree, a choice that is fairly surprising. The term 'thorn' or 'thorns' in the scriptures (see, e.g., Hs 10:8) and in the rabbinical literature is usually a collective noun (Cohen 1949:219-221; Amar 2012:235). The thorn is a harmful plant that is usually useless (torturing by thorns is mentioned in Jdg 8:7: 'I will flail your flesh with the thorns of the wilderness and with briers', but not for hanging or execution). Because of this quality, it is presented as lacking virtues and having no symbolic affiliation with the Jewish world of religious precepts and, above all, unlike the other trees, it does not symbolise the Jewish collective in any way (on biblical plants in the Midrash, see Shemesh 2019). The question that begs to ask is why does the exegetist nonetheless see it as worthy of being the gallows, and, moreover, why was it chosen for this task promptly and unquestioningly?

The choice of a thorn tree might reflect the heavy and painful punishment that befits the cruel Haman (a measure for a measure). Another explanation for this choice is also possible. God sought a tree that would 'sacrifice itself' to hang Haman. While the rest of the trees tried to prove their worthiness by citing their virtues or special symbolism, the thorn tree is the only one that is aware of its demerits and that presents itself modestly and submissively.

The message of the exegetist is that ultimately the right to be saved from a decree of destruction does not necessarily stem from many virtues and great spiritual force, rather even in a state of lack of virtues and perhaps emptiness, it is possible to elude a bad decree if the subject of this decree is endowed with modesty and honest self-awareness.

The suggestion that the tree on which Haman was hanged was a 'myrtle' or 'thorn' indicates that when the message is educational, the exegetist is free of rational concepts of time and reality, and the proposed identification may be unrealistic. Regarding the disregard of the Midrash for reality or for historical factors, Heinemann (1970:192, 1974:163-165) has already stated that in some cases, 'the sages were not averse to descriptions that are incompatible with the biblical stories ... and saw themselves entitled to neglect ... the historical facts'. Similarly, Fraenkel (1996:308-311, 2001:22) argued for a genre of the 'imaginary homiletic story', that is, texts that are 'literary and artistic, that do not reflect a realistic state of affairs rather a literary one'.

\section{Discussion and conclusions}

The biblical narrator conveys his messages matter-of-factly, with no need for details that are not essential for the story's contents. The task of the author of the Midrash is to clarify the text and to complement the story by adding missing realistic details (Mack 1989:102). He also utilises data that were mentioned in the scriptures but not further developed and finds in them new meanings that serve his theological aims (Mack 1989:100).

In fact, both the Targum Rishon and the Midrash aggadah sought to enhance the details described regarding the occurrences in Haman's personal house and the decision to hang Mordechai from a gallows. The text relates to this event fairly laconically. The two Midrashic sources, in contrast, portray an entire scene that includes discourse, deliberations and choice - in Haman's house and in heaven. The author of the Targum focusses on the corporeal space, that is, the deliberations of Haman and his supporters regarding the suitable punishment for Mordechai. His interpretation joins other Midrashim that reveal details of hidden meetings between various characters that are not described in the text, such as the meeting between Haman and Ahasuerus, where the 
decision to eliminate all Jews in the Persian kingdom is reached (3:8-11). The Midrash presents a list of reasons that are not mentioned in the text, by which Haman convinces Ahasuerus that it is worthwhile and fitting to eliminate the Jews - because they do not marry Persian women, do not pay taxes, scorn the royal house and do not work because of their many festivals (Babylonian Talmud 1882, Megilah 13b; Ben Eliezer 1989:31).

In contrast to the Aramaic Targum, which does not include God in the decision to execute Mordechai, the Midrash aggadah presents the choice of the thorn tree as reflecting divine intervention. Haman's choice of the thorn tree was in fact determined by God, unknown to Haman, after various plants professed their suitability for the task. The Midrash aggadah is distinct from the Masoretic version not only in its Midrashic and aggadic nature but also in its theological orientation. While God's name is not mentioned in the Masoretic version at all, and there is no allusion to his intervention in the course of events, the Midrash fills the theological 'vacuum' by presenting a narrative that includes God's hidden intervention (on theology and religion vs. secularism in the Book of Esther, see Ararat 1980:223-236; Crenshaw 1969:129-142; Fox 1990:135-147; Grasham 1973:99-111; Koller 2014:96-101; Talmon 1963:419-455).

This tendency is also evident in other Midrashims that identify certain parts of the plot as divine intervention. One of the turning points was identified in the verse, 'On that night the king could not sleep' (6:1), which according to the Midrash is a reference to God - that is, 'The King of the Universe could not sleep' (see Babylonian Talmud 1882, Megilah 15b; Esther Rabbah 1885-1887:28; Buber 1887:47-48). The king's sleeplessness serves as a literary means in order to bring the topic to its final conclusion. According to the Midrash, God is concerned about the imminent danger so he creates a chain of events that eventually brings about the fall of Haman. Indeed, from the night Haman comes to the palace to ask the king to hang Mordechai, a radical change is evident in his lofty status and ultimately he is the one who hangs from the tree.

\section{The nature of the discourse at Haman's house and in heaven: Text and Midrash}

In order to understand the meaning of the discourse in Haman's house, in the text of the Book of Esther and in the Midrashim, a short review of the nature of these conversations is in order. The primary function of conversations, in biblical stories in general and in the Book of Esther in particular, is to advance the plot. Sometimes, conversations constitute the most important part of a plot and at times they generate the turning points, for example, the dismissal of Queen Vashti is decided by a demagogic speech given by minister Memuchan (1:16-20). A conversation is usually defined as an incident of speech and response between two people. Any talk by one of the interlocutors is called a 'move'.
In the Book of Esther, there are 16 conversations, mostly short, consisting of one $(1: 16-20 ; 2: 2-4 ; 5: 5 ; 6: 13 ; 7: 8)$ or two moves (3:8-11; 5:3-4, 6-8, 12-14; 7:9; 8:5-8; 9:12-13). On these two structures, see Klein (2002:221). In 14 of the 16 conversations, the king is one of the two interlocutors. All the conversations in the book have only two speakers. In the conversation in the house of Haman, many people (Zeresh and Haman's loved ones) speak a single agreed utterance (to hang Mordechai from a tree) and hence are considered a single interlocutor (5:14).

The Targum and the Midrash Aggadah, each in its own way, see the conversations that take place between the different characters as a key for understanding the events and a tool for obtaining theological meaning. According to the Midrash Aggadah, the conversation in Haman's house 'advances the plot' differently than the text. While, according to the text, this is a negative fateful point in Mordechai's life, the Midrash aggadah presents it as a positive turning point that reflects God's intervention in the course of affairs.

Moreover, while according to the text there are two speakers in Haman's house, with only two 'moves', the Targum 'opens' the conversation to other speakers, opinions and suggestions, such that a complex and diverse picture and a set of arguments underlie the 'single and agreed' utterance.

The Midrash aggadah enriches our understanding of the situation from another aspect. It gives God an opportunity to sound his voice at a very critical stage of the story, where the fate of Mordechai and of the people of Israel as a whole is debated. As stated, Ahasuerus, the earthly king, takes part in 14 of the 16 conversations in the book by virtue of his status and authority, while God, who governs the world de facto, is silent and observes the world from a seemingly separated position. The hidden conversation that takes place in heaven is the antithesis of the conversation in Haman's house. Aside from its aim to repeal the decision of those gathered, it is also conducted differently. The short conversations at the palace and at Haman's house reflect the tyranny practised by people in ruling positions. The dialogue between God and the trees includes more steps and speakers. During the discourse, God is revealed as attentive to the arguments of each and every tree and finally, surprisingly, he chooses the most marginal plant, perhaps as an expression of justice and of attention to the disadvantaged.

\section{The interpretations offered by the Targum and by the Midrash aggadah: Similarity and dissimilarity}

Similarity and dissimilarity points can be found in the approach of the Midrashic sources discussed to the gathering at Haman's house with regard to Mordechai's execution. According to the Midrash aggadah, Haman is not aware of the salvation that Mordechai is about to experience and he chooses the tree, confident that it will be used to 
hang Mordechai. According to the Targum, in contrast, Haman is aware of the likelihood that Mordechai might escape his execution in some way and therefore he seeks a punishment for which there is no precedent of a miracle for any Jewish figure.

In fact, both interpretations, of the Targum and of the Midrash aggadah, see the fateful moment in Mordechai's life as a sign of Haman's weakness. According to the Targum, Haman's weakness is manifested in the nearly desperate search for a 'safe' punishment for Mordechai. Those gathered propose 11 methods of killing, but these are all rejected because of the concern of a miracle. The narrative of the Midrash aggadah, whereby plants are recruited to bring down Haman and in favour of Mordechai, also indicates that nature and the vegetative world serve and act on behalf of the righteous and therefore each of them is willing to offer itself up as the plant on which Haman will hang (On punishing the wicked by nature elements see Redditt 2003: 261).

Several conversations in the Book of Esther take place clandestinely, with the characters or groups who will be adversely affected by the decisions not aware of the fate that awaits them. The Jews are not aware of the meeting between Haman and the king regarding their annihilation (3:8-11), and Bigtan and Teresh secretly decide to assassinate King Ahasuerus (2:21-23). In the same way, Haman is unaware of the king's conversation with his servants about rewarding Mordechai for preventing the assassination (6:3-5). Unknowingly, Haman advises the king on how to grant his arch-enemy, Mordechai, royal honours, and he himself is then compelled to carry out the ceremony, as humiliating as it is for him (6:6-11).

The Targum Rishon and the Midrash aggadah have in common the attempt to reveal that which took place in these clandestine conversations. The Targum Rishon reveals the details of the clandestine conversation concerning the execution of Mordechai, of which Mordechai is unaware, while the Midrash aggadah reveals the clandestine conversation in heaven between God and the trees, of which no one is aware, particularly Haman who is to bear its results. The sources differ, as the Aramaic translation fills the conversation with content following the story related in the text, while the Midrash aggadah 'generates' a new dialogue that is not insinuated in any way in the text.

While the attempts of God and of the plants to help save Mordechai focus on the support and help needed by the good person who is persecuted by the evil, the Targum may have described in detail the deliberations about how to kill Mordechai in order to strengthen the impression of Haman as a cruel and dangerous force. According to the Targum, Haman sees Mordechai as a dangerous element that might cause much damage, but the author is interested in showing that Haman himself is even more dangerous.
It is not impossible that the occupation with Haman's scheme of brutally killing Mordechai is aimed at justifying the killing of Agag by Samuel. The exegetist reveals the cruelty of Agag's descendants in order to show that the elimination of Agag himself was justified.

\section{Acknowledgements Competing interests}

The authors have declared that no competing interest exist.

\section{Author's contributions}

I declare that I am the sole author of this research article.

\section{Ethical consideration}

This article followed all ethical standards for a research without direct contact with human or animal subjects.

\section{Funding information}

This research received no specific grant from any funding agency in the public, commercial or not-for-profit sectors.

\section{Data availability statement}

Data sharing is not applicable to this article as no new data were created or analysed in this study.

\section{Disclaimer}

The views and opinions expressed in this article are those of the authors and do not necessarily reflect the official policy or position of any affiliated agency of the authors.

\section{References}

Abbott, G., 2012, Execution: A guide to the ultimate penalty, Summersdale Publishers, Chichester.

Albeck, H.., 1952, Mishnah, Mossad Biyalik and Dvir, Jerusalem and Tel Aviv.

Amar, Z., 2012, Plants of the Bible, Reuven Mass, Jerusalem. [Heb.]

Ararat, N., 1980, 'The secularism of book of Esther and its revulsions', Tarbitz 49, 223-236. [Heb.]

Atzmon, A., 2005, 'Esther Rabbah II: Towards a critical edition', PhD thesis, Bar-Ilan University, Ramat-Gan. [Heb.]

Atzmon, A., 2011, 'Late neo-classical Midrash: Redaction and formation', in A. Amit \& A. Shemesh (eds.), Melekhet Mahshevet: Studies in the redaction and development of Talmudic literature, pp. 87-100, Bar-Ilan University Press, Ramat-Gan. [Heb.]

Babylonian Talmud, 1882, The Widow and Brothers Romm, Vilna.

Bammel, E., 1970, 'Crucifixion as a punishment in Palestine', in E. Bammel (ed.), The trial of Jesus: Studies in honour of C. F. D. Moule, pp. 162-165, A.R. Allenson, Naperville, IL.

Bauman, R.A., 2005, Crime and punishment in ancient Rome, Routledge (rep. 1996), London \& New York, NY.

Ben Eliezer, T., 1989, Midrash Lekach Tov, Vagshal, Jerusalem (facsimilia, Shlomo Buber edition Krakow 1897).

Berg, S.B., 1979, The book of Esther: Motifs, themes, and structure, Scholars Press, Missoula, MT.

Buber, S., 1887, Sifri De-aggadetah on book of Esther-Midrash Panim Acherim, The Widow and Brothers Romm, Vilna.

Cohen, A., 1949, 'To the identification of the Shamir and Shaite', Leshonenu 23, 219-221. [Heb.]

Cook, J.G., 2014, Crucifixion in the Mediterranean world, Wissenschaftliche Untersuchungen zum Neuen Testament (WUNT) 327, Mohr Siebeck, Tübingen. https://doi.org/10.1628/978-3-16-153125-5 
Crenshaw, J.L., 1969, "Method in determining wisdom influence upon "historical" literature', Journal of Biblical Literature (JBL) 88, 129-142. https://doi.org/ $10.2307 / 3262873$

Elboyim, B., 2011, 'Midrash Abba Gurion on Esther: The version and its redactions', PhD thesis, Bar-Ilan University, Ramat-Gan. [Heb.]

Esther Rabbah, 1885-1887, The Widow and Brothers Romm, Vilna.

Fox, M.V., 1990, 'The religion of the book of Esther', Judaism 39, 135-147.

Fraenkel, J., 1996, The ways of the aggada and the Midrash, Yad La-Talmud, Tel Aviv. [Heb.]

Fraenkel, J., 2001, The aggadic narrative: Harmony of form and content, Ha-Kibbutz Ha-Meuchad, Tel Aviv. [Heb.]

Futrell, A., 2001, Blood in the arena: The spectacle of Roman power, University of Texas Press, Austin, TX.

Goes, F.J., 2013, The eye in history, Jaypee Brothers, New Delhi.

Grasham, W.W., 1973, 'The theology of the book of Esther', Restoration Quarterly 16 99-111.

Grossfeld, B., 1983, The first Targum to Esther: According to the MS. Paris Hebrew 110 of the Bibliothèque nationale, Sepher-Hermon Press, New York, NY.

Grossfeld, B., 1994, The Targum Sheni to the book of Esther: A critical edition based on MS. Sassoon 282 with critical apparatus, Sepher-Hermon Press, New York, NY.

Ha-Reuveni, N., 1991, Desert and shepherd in Israel Heritage, Neot Kedumim, Givatime. [Heb.]

Haupt, P., 1908, 'Critical notes on Esther', The American Journal of Semitic Languages and Literatures 24(2), 97-186. https://doi.org/10.1086/369606

Heinemann, I., 1970, The methods of aggadah, Magnes and Mssada, Jerusalem. [Heb.]

Heinemann, J., 1974, Aggadot Ve-toledotehen (=Aggadah and its development), Keter, Jerusalem. [Heb.]

Herodotus, 1926, The histories, transl. A.G. Denis, Loeb Classical Library, Harvard University Press, Cambridge, MA.

Holm, T.L., 2008, 'The fiery furnace in the book of Daniel and the ancient near east', Journal of the American Oriental Society 128(1), 85-104.

Jacobs, B., 2009, 'Grausame Hinrichtungen - friedliche Bilder, Zum Ver-hältnis de politischen Realität zu den Darstellungsszenarien der achäme-nidischen Kunst', in M. Zimmermann (ed.), Extreme Formen von Gewalt in bild und text des Altertums, Münchner Studien zur Alten Welt 5, pp. 121-153, Utz, München.

Jastrow, M., 1903, Dictionary of the Targumim, the Talmud Babli and Yerushalmi, and the Midrashic literature, Luzac, London.

Jerusalem Talmud, 1523, Daniel Bomberg, Venice.

Kasher, A., 1983, The great Jewish revolt: Factors and circumstances leading to its outbreak, Merkaz Zalman Shazar, Jerusalem. [Heb.]

Klein, J., 2002, Scrolls: The Bibles' world, Divrei ha-Yamim, Tel Aviv. [Heb.]

Koch, K., 2001, 'Stages in the canonizations of the Book of Daniel', in J.J. Collins, P.W. Flint \& C. Van Epps (eds.), The book of Daniel: Composition and reception, vol. 2 pp. 421-446, Brill, Leiden.

Koller, A., 2014, Esther in ancient Jewish thought, Cambridge University Press, Cambridge.

Lascaratos, J. \& Marketos, S.G., 1992, 'The penalty of blinding during Byzantine times: Medical remarks', Documenta Ophthalmologica 81(1), 133-144. https://doi. org/10.1007/BF00155023

Leviticus Rabbah, 1885-1887, The Widow and Brothers Romm, Vilna.

Loader, J.A., 1978, 'Esther as a novel with different levels of meaning', Zeitschrift fiir die alttestamentliche Wissenschaft (ZAW) 90, 417-421.
Mack, H., 1989, The aggadic Midrash literature, Ministry of Defense, Tel Aviv. [Heb.]

Mandelbaum, B., 1962, Pesikta de-Rav Kahana, Jewish Theological Seminary of America, New York, NY.

Middlemas, J., 2011, 'Greek Esthers and the search for history: Some preliminary observations', in B.E.J.H. Becking \& L. Grabbe (eds.), Between evidence and ideology: Essays on the history of ancient Israel read at the joint meeting of the society for Old Testament study and the Oud Testamentisch Werkgezelschap Lincoln, July 2009, pp. 145-163, Brill, Leiden.

Mullen, J. \& Popalzai, M., 2015, 'Woman stoned to death in Afghanistan over accusation of adultery', CNN, 04 November, 2015, viewed 01 'October 2019, from https://edition.cnn.com/2015/11/04/asia/afghanistan-taliban-woman-stoning/ index.html.

Paton, L.B., 1908, A critical and exegetical commentary on the Book of Esther, The International Critical Commentary (ICC), T\& T Clark, Edinburgh.

Pearman, T.V., 2010, Women and disability in Medieval literature, Palgrave Macmillan, New York, NY.

Rabinovitch, Z.M., 1976, Ginzee Midrash, Tel Aviv University, Tel Aviv. [Heb.]

Rappaport, U., 1984, A history of Israel in the period of the Second Temple, Amikhai, Tel-Aviv. [Heb.]

Redditt, P.L., 2003, 'Punish, punishment', in D.E. Gowan (ed.), The Westminster theological wordbook of the Bible, John Knox Press, Westminster, Louisville, KY.

Robinson, O.F., 2007, Penal practice and penal policy in ancient Rome, Routledge, London \& New York, NY.

Robison, J.C., 2002, 'Crucifixion in the Roman world: The use of nails at the time of Christ', Studia Antiqua 2(1), 25-59.

Rose, M.L., 2003, The staff of Oedipus: Transforming disability in ancient Greece, The University of Michigan Press, Ann Arbor, MI.

Samuelsson, G., 2011, Crucifixion in antiquity: An inquiry into the background and significance of the New Testament terminology of crucifixion, Mohr Siebeck, Tübingen.

Segal, M.Z., 1967, Introduction to the Bible, Kiryat Sefer, Jerusalem. [Heb.]

Shemesh, A.O., 2019, "The rabbis maintained that it was Flaxseed": The identification and interpretation of unidentified Biblical plants in aggadic homilies', Biblical Theology Bulletin 49(3), 156-168. https://doi.org/10.1177/ 0146107919852274

Shinan, A., 1987, The world of the aggadic literature, Ministry of Defense, Tel Aviv. [Heb.]

Stumpf, J.A., 2017, 'On the mutilation and blinding of Byzantine emperors from the reign of Heraclius I until the fall of Constantinople', Journal of Ancient History and Archaeology 4(3), 46-54. https://doi.org/10.14795/j.v4i3.265

Talmon, S., 1963, 'Wisdom in the book of Esther', Vetus Testamentum (VT) 13(1), 419-455. https://doi.org/10.1163/156853363X00352

Theis, C., 2016, 'Methods of death penalty in ancient near eastern cultures', in S. Nowicki (ed.), 'They called me to destroy the wicked and the evil': Selected essays on crime and punishment in antiquity, pp. 247-263, Ugarit-Verlag, Münster.

Theodor, J. \& Albeck, H., 1903, Genesis Rababh, Itzkowski, Berlin.

Weiland, F.S., 2002, 'Historicity, genre, and narrative design in the book of Esther', Bibliotheca Sacra 159(634), 151-165.

Welch, M., 2004, Corrections: A critical approach, McGraw-Hill, New York, NY.

Yalkut Shimoni, (attributed to R. Simeon of Frankfurt), 1975, Anonymous Press, Jerusalem.

Zias, J., 1985, 'The crucified man from Giv'at Ha-Mivtar: A reappraisal', Israe Exploration Journal 35(1), 22-27. https://doi.org/10.2307/3209939

Zakovitch, Y. \& Shinan, A., 2017, Lamentations: A new Israeli commentary, Miskal, Jerusalem. 